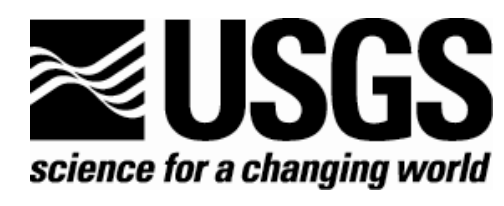

\title{
Geochemistry of Sediments in Cores and Sediment Traps from Bear Lake, Utah and Idaho
}

By James L. Bischoff, Kathleen Cummins, and Donald D. Shamp

Open-File Report 2005-1215

U.S. Department of the Interior

U.S. Geological Survey 


\section{U.S. Department of the Interior \\ Gale A. Norton, Secretary}

\section{U.S. Geological Survey \\ Charles G. Groat, Director}

\section{U.S. Geological Survey, Reston, Virginia 2005}

For sale by U.S. Geological Survey, Information Services

Box 25286, Denver Federal Center

Denver, CO 80225

For more information about the USGS and its products:

Telephone: 1-888-ASK-USGS

World Wide Web: http://www.usgs.gov/

Any use of trade, product, or firm names in this publication is for descriptive purposes and does not imply endorsement by the U.S. Government.

Although this report is in the public domain, permission must be secured from the individual copyright owners to reproduce any copyrighted material contained within this report.

This report has not been reviewed for stratigraphic nomenclature.

Suggested citation:

Bischoff, J.L., Cummins, K., and Shamp, D.D., 2005, Geochemistry of sediment in cores and sediment traps from Bear Lake, Utah and Idaho: U.S. Geological Survey Open-File Report 2005-1215, 17p.

Prepared by the U.S. Geological Survey in Denver, Colorado (http://climchange.cr.usgs.gov/) 


\title{
Geochemistry of Sediments in Cores and Sediment Traps from Bear Lake, Utah and Idaho
}

\author{
By James L. Bischoff, Kathleen Cummins, and Donald D. Shamp
}

\section{Introduction}

The present study of Bear Lake began in 1998. Initially, the study utilized sediments from three long cores (up to $5 \mathrm{~m}$ ) previously collected in 1996 and short cores (up to $40 \mathrm{~cm}$ ) collected in 1998. The short cores were specifically acquired to preserve the uppermost layers of sediment that may have been lost in the long cores. In addition, three arrays of sediment traps were deployed during the summer of 1998, and sediment from these traps was collected during the summers of 1999 and 2000 (see Dean and others, 2005 , for core and sediment trap locations). The cores and sediment traps were sampled, and splits were distributed to various investigators for analyses of a wide variety of sediment parameters. The chemical composition of the acid-soluble component of the sediments is presented in this report. $\mathrm{HCl}$ or $\mathrm{HNO}_{3}$ treatment of the sediment quantitatively dissolves the authigenic component of the sediment, a component that includes carbonates, sulfates, and iron-mono sulfides. In the case of Bear Lake, $\mathrm{CaCO}_{3}$ is the major component of the sediment today and for most of the Holocene (Dean and others 2005). The chemical composition of the acid-soluble fraction gives important information on this component and, therefore, insight into the chemical conditions of the lake at the time of carbonate deposition.

\section{Sampling}

The 1996 and 1998 cores were cut into 1-cm-thick wafers. For the 1998 cores, a split of every wafer was taken for analysis of the acid-soluble component, whereas for the 1996 cores a split of every fourth (for example, 4-5 cm, 8-9 cm, 12-13 cm, and so forth) was taken. The samples were dried, lightly ground and homogenized, and separated into aliquots for distribution to cooperating laboratories.

\section{Analytical Techniques}

Sample splits of 0.5 gram were leached in 10 milliliters of $3 \mathrm{~N} \mathrm{HCl}$ overnight, and the supernate was analyzed by inductively coupled plasma atomic emission spectrometry (ICP-AES) for major components $\mathrm{Ca}, \mathrm{Mg}$, and $\mathrm{Fe}$, and minor components $\mathrm{Na}, \mathrm{Li}, \mathrm{Mn}, \mathrm{Ti}$, $\mathrm{Ba}$, and Sr. In addition, samples from core 96-3 also were analyzed on a bulk basis by 
performing total dissolution in a mixture of $\mathrm{HF}$ and $\mathrm{HNO}_{3}$. For these samples, a larger suite of elements was analyzed - Al, Ca, Mg, Fe, K, Ti, P, S, Mn, Ag, Co, Cr, Cu, Li, Ni, $\mathrm{Pb}, \mathrm{Sr}, \mathrm{V}, \mathrm{Y}$, and $\mathrm{Zn}$.

\section{Results}

Results for the leachable component of the 1996 cores are in Appendixes 1, 2, and 3, for the bulk composition of 96-3 are in Appendix 4, for the leachable component of the 1998 cores are in Appendixes 5, 6, and 7 and for the sediment trap-samples are in Appendix 8. We highlight some of the main patterns in authigenic sediment composition in the following paragraphs.

\section{6 long cores}

First we consider the 1996 long cores. Sedimentation rates, as indicated by radiocarbon dates presented in Colman and others (2005), are slowest in the west (core 96-3) and fastest in the east (core 96-1). A radiocarbon date of 10.9 kyrs was obtained on pollen taken from $20 \mathrm{~cm}$ depth in core $96-3$. Thus, most of the $400 \mathrm{~cm}$ length extends into the Pleistocene. A depth plot of bulk $\mathrm{Ca}$ and acid leachable $\mathrm{Ca}$ for this core (fig. 1) indicates that essentially all $\mathrm{Ca}$ is acid-leachable and is, therefore, attributed to $\mathrm{CaCO}_{3}$. Therefore, leachable $\mathrm{Ca}$ is attributed to $\mathrm{CaCO}_{3}$ and is plotted with depth in each core. Depth plots of $\mathrm{CaCO}_{3}, \mathrm{Sr} / \mathrm{Ca}, \mathrm{Mg} / \mathrm{Ca}$ and $\mathrm{Fe}$ (Fe on carbonate-free basis, CFB) serve as indicators of changes in the authigenic components. Fe is studied on a carbonate-free basis to remove the dilution effect of $\mathrm{CaCO}_{3}$, thereby revealing actual changes in the character of $\mathrm{Fe}$ in the noncarbonate fraction, whether terrigenous or diagenetic sulfides. $\mathrm{CaCO}_{3}$ is the major sediment component during periods when Bear Lake was isolated from input from Bear River, whereas it is significantly diluted by alumino-silicate terrigenous material when the lake was flooded by Bear River during high-water flow of the last glacial interval. $\mathrm{Sr} / \mathrm{Ca}$ gives an indication of $\mathrm{CaCO}_{3}$ mineralogy - high values when aragonite predominates, low values when calcite predominates. $\mathrm{Mg} / \mathrm{Ca}$ gives an indication of the relative importance of magnesian carbonates (high-Mg calcite, dolomite), whereas high values of Fe reflect the abundance of authigenic Fe monosulfides and, thus, of redox conditions. Figure 2 shows these proxies for core 96-3. Low values of $\mathrm{CaCO}_{3}$ and $\mathrm{Fe}$ are seen extending from the bottom of the core at $400 \mathrm{~cm}$ up to the topmost 50-60 $\mathrm{cm}$ where these proxies increase rapidly and abruptly. $\mathrm{CaCO}_{3}$ continues to increase to the top of the core, whereas Fe peaks at about $20 \mathrm{~cm}$ and drops abruptly back to values typical of the lower part of the core. The Fe peak corresponds to a zone for which magnetic data (Rosenbaum, 2005) suggest the presence of greigite, a highly magnetic Fe sulfide. This abrupt change represents a major change in the character of the sediments from terrigenous dominated to authigenic dominated, most likely signaling the lowering of Bear River flow and the isolation of the lake at the Pleistocene-Holocene transition. The transition was characterized by a short period of anoxicity wherein Fe monosulfides were produced in the sediment. Figure 3 shows the same proxies plotted for core 96-2 taken near the middle of the lake. Fe displays high values from 400 to 300 $\mathrm{cm}$ and then drops abruptly to low and rather constant values to the top of the core. The abrupt drop in Fe corresponds to an abrupt increase in $\mathrm{CaCO}_{3}$. The boundary coincides with a radiocarbon date of ca 12.7 kyrs (Colman and others, 2005), and probably 


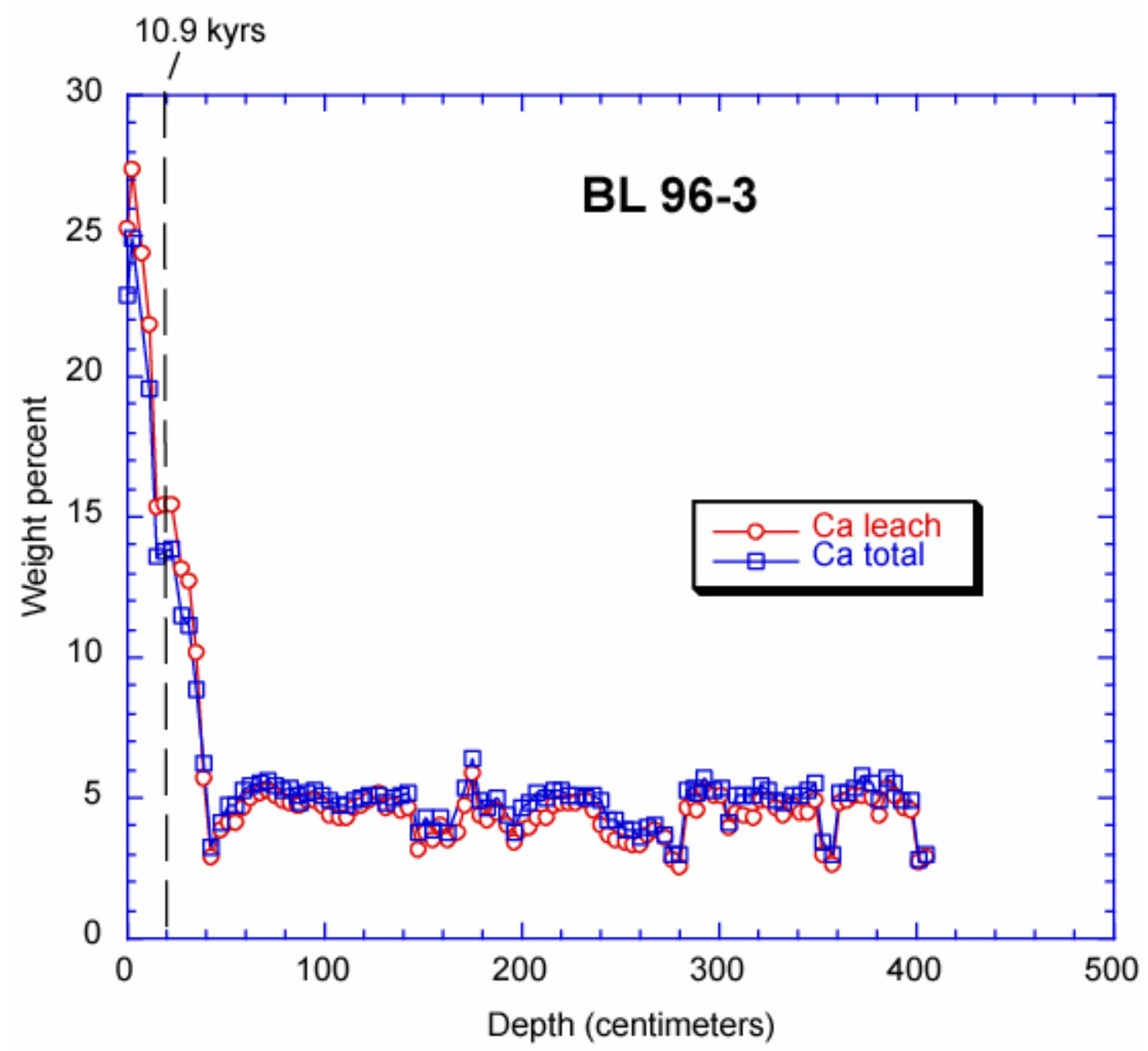

Figure 1. Acid leachable $\mathrm{Ca}$ and total $\mathrm{Ca}$ (bulk) plotted together versus depth for Bear Lake core 96-3, data from appendices 3 and 4. Data show that essentially all $\mathrm{Ca}$ is in the acid-leachable fraction, representing $\mathrm{CaCO}_{3}$.

represents the same boundary as seen at $50-60 \mathrm{~cm}$ in core $96-3$. The $\mathrm{Mg} / \mathrm{Ca}$ plot provides a more exact correlation between the two cores. A sharp peak in $\mathrm{Mg} / \mathrm{Ca}$ is seen at $330 \mathrm{~cm}$ in core 96-2 and occurs at $42 \mathrm{~cm}$ in core 96-3. Above $300 \mathrm{~cm}$ and all the way to the top in core 96-2, the sediment is dominated by $\mathrm{CaCO}_{3}$. In this region, changes in $\mathrm{Sr} / \mathrm{Ca}$ are seen that reflect changes in carbonate mineralogy. X-ray diffraction mineralogy (Dean and others, 2005) shows aragonite dominating from 240 to $205 \mathrm{~cm}$ and from $192 \mathrm{~cm}$ to the top of the core. These zones are marked by relatively high values of $\mathrm{Sr} / \mathrm{Ca}$ (fig. 4), whereas the calcite-dominated zones are characterized by low values of $\mathrm{Sr} / \mathrm{Ca}$. $\mathrm{Sr}$ can readily substitute for $\mathrm{Ca}$ in the larger cation site of aragonite compared to calcite. However, the $\mathrm{Sr} / \mathrm{Ca}$ ratio varies smoothly within the aragonite zones as well, suggesting slow evolution of precipitation conditions rather than static conditions during these times in the late Holocene. Changes from calcite domination to aragonite domination imply rather significant changes in lake chemistry - the nature of which is unclear. Core 96-1 

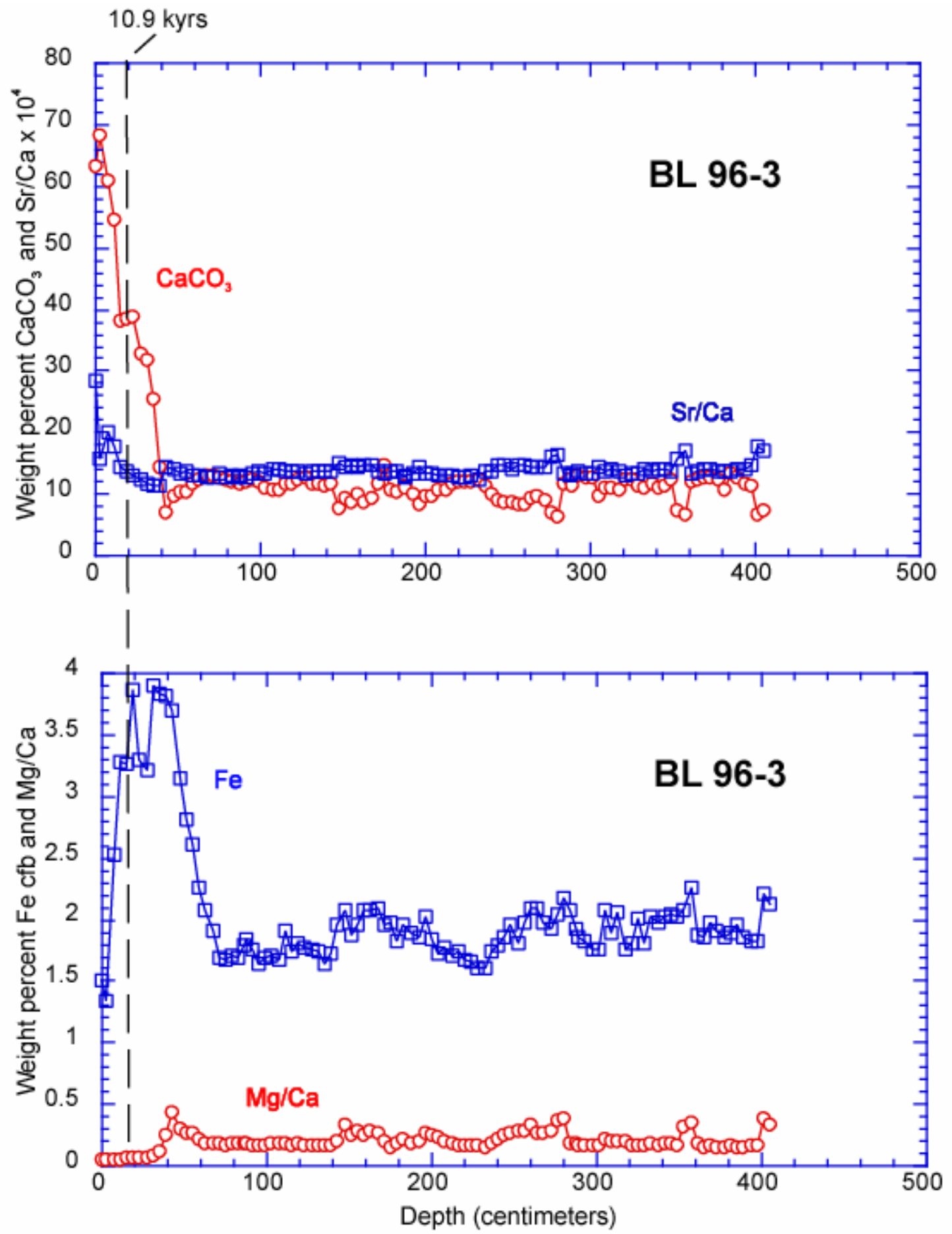

Figure 2. $\mathrm{CaCO}_{3}$ content, $\mathrm{Sr} / \mathrm{Ca}$, Fe content on a carbonate-free-basis (cfb), and $\mathrm{Mg} / \mathrm{Ca}$ for Bear Lake core 96-3 derived from chemical composition of the acid soluble component of the sediments (Appendix 3) plotted against depth. 

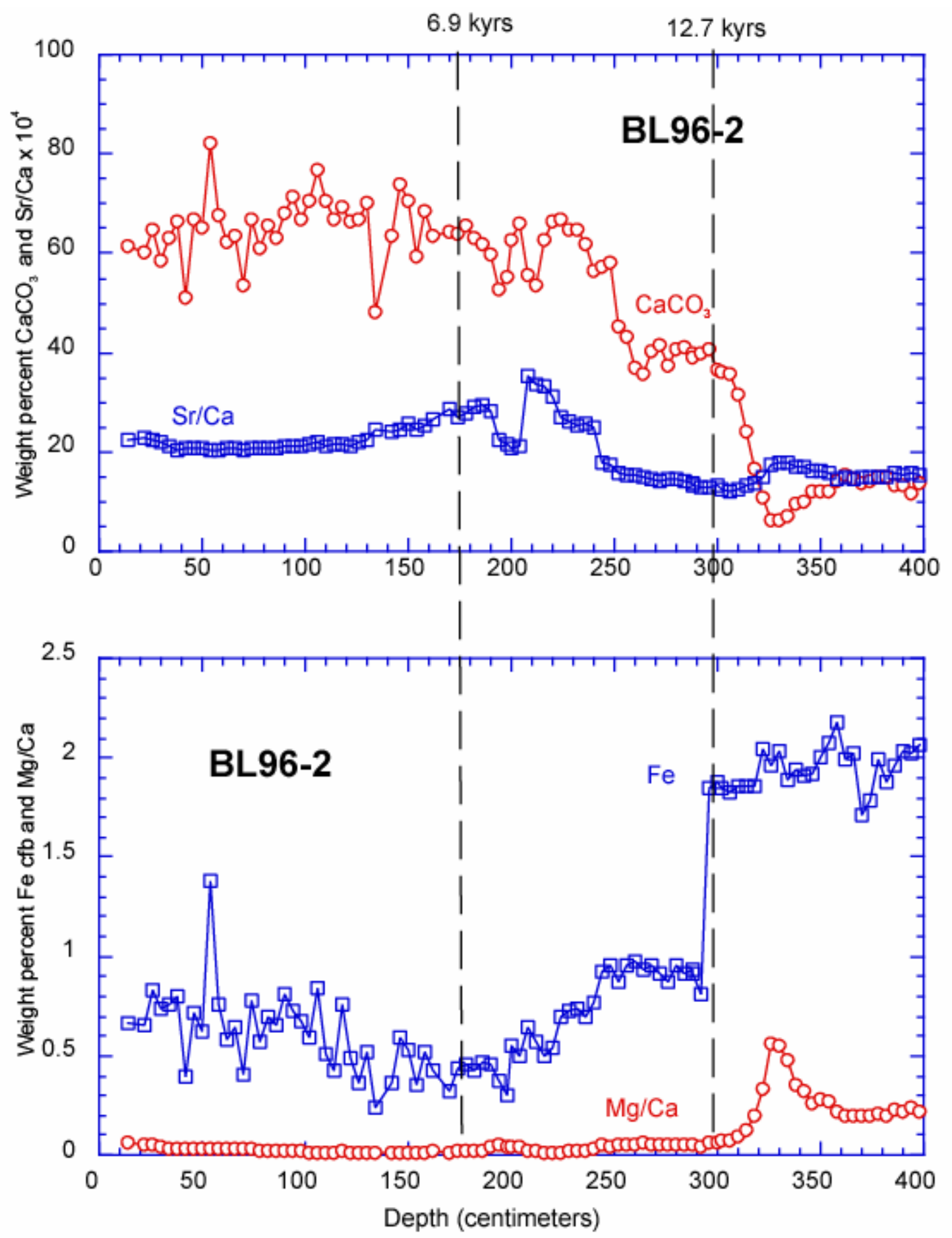

Figure 3. $\mathrm{CaCO}_{3}$ content, $\mathrm{Sr} / \mathrm{Ca}$, Fe content on a carbonate-free-basis (cfb), and $\mathrm{Mg} / \mathrm{Ca}$ for Bear Lake core 96-2 derived from chemical composition of the acid soluble component of the sediments (Appendix 2) plotted against depth. 


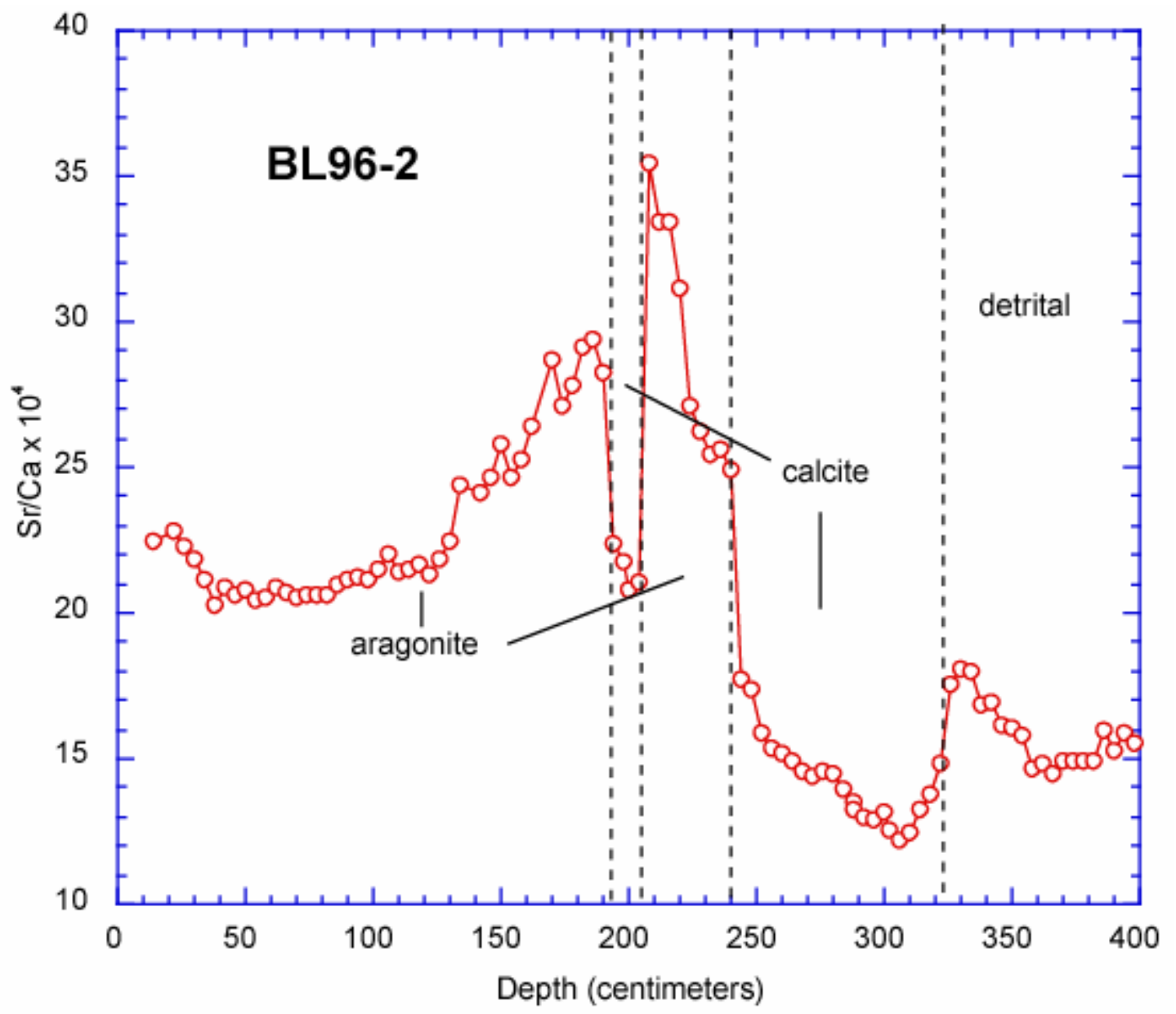

Figure 4. Sr/Ca for core 96-2 plotted on expanded scale versus depth, showing its relation to aragonite and calcite-rich zones (mineralogy from Dean and others, 2005).

(fig. 5), taken near the eastern shore of the lake, contains rather homogeneous, high$\mathrm{CaCO}_{3}$ sediment, characterized by constant $\mathrm{Sr} / \mathrm{Ca}, \mathrm{Mg} / \mathrm{Ca}$. Fe content is generally low but displays some variation on a millennial time scale. Radiocarbon dates of $6.7 \mathrm{kyr}$ at $493 \mathrm{~cm}$ and $3.3 \mathrm{kyr}$ at $252 \mathrm{~cm}$ indicate the entire core extends back only to the midHolocene and represents rather constant and unchanging conditions of sedimentation.

1998 short cores

Short cores (20-40 cm length) were taken in order to preserve the uppermost layers of sediment that may have been lost in the long cores and to provide a high resolution record of the recent-most few hundred years. Cores 98-6 and 98-10 were taken at locations very near the respective locations of long cores 96-3 and 96-2 whereas 98-12 was centrally located in the northern part of the lake (Dean and others, 2005).

Sedimentation rates were determined for cores $98-6$ and $98-10$ by Smoak and Swarzenski (2004) and for core $98-12$ by Swarzenski (written commun.) using profiles of ${ }^{210} \mathrm{~Pb}$ in the sediment. Their chronologies allow interpolation to locate the depth representing the Bear River diversion event to be between 1909 and 1918. Before diversion and 

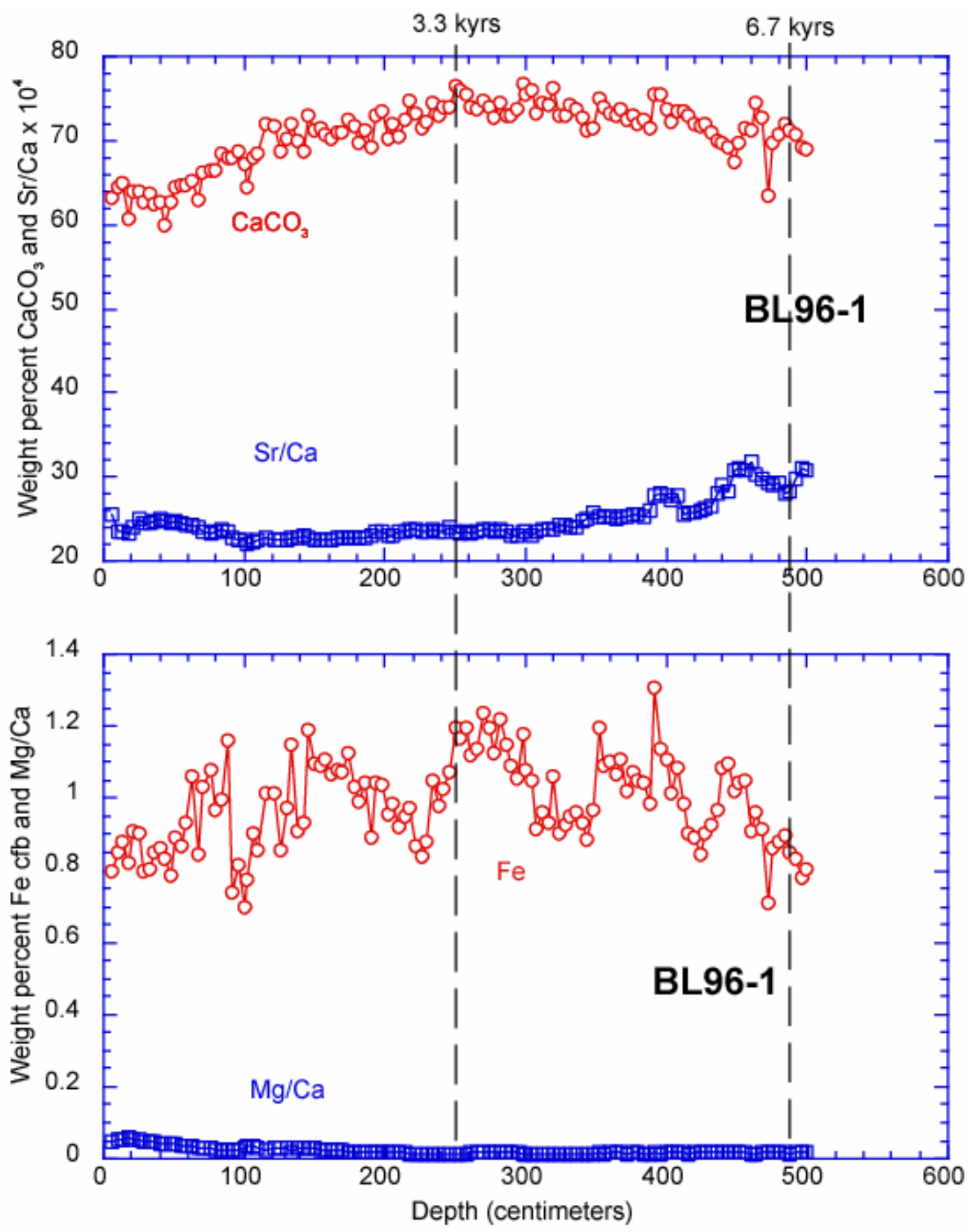

Figure 5. $\mathrm{CaCO}_{3}$ content, $\mathrm{Sr} / \mathrm{Ca}, \mathrm{Fe}$ content on a carbonate-free-basis (cfb), and $\mathrm{Mg} / \mathrm{Ca}$ for Bear Lake core 96-1 derived from chemical composition of the acid soluble component of the sediments (Appendix 1) plotted against depth. 
throughout much of the Holocene, no water from Bear River flowed into the lake. Hereinafter, we use 1912 as the time of diversion, the date of the first chemical analysis of Bear Lake water (Kemmerer and others, 1923). Thus, in 1912, the lake became a reservoir with the water of Bear River conducted into the lake through a series of canals (Williams, 1961). This event is clearly marked by significant increases in the $\mathrm{Sr} / \mathrm{Ca}$ ratio and $\mathrm{Fe}$ in the two southern cores and by $\mathrm{Sr} / \mathrm{Ca}$ alone in the northern core (98-12). Data for core 98-06 (fig. 6) show a significant and abrupt increase in $\mathrm{Sr} / \mathrm{Ca}$ and $\mathrm{Fe}$ at about 7 $\mathrm{cm}$, signaling the 1912 event that ${ }^{210} \mathrm{~Pb}$ results indicate to be about $8 \mathrm{~cm}$ (Smoak and Swarzenski, 2004). In contrast, $\mathrm{CaCO}_{3}$ content remains around $60-70$ percent and $\mathrm{Mg} / \mathrm{Ca}$ remains between $0.2-0.3$ for the entire $20 \mathrm{~cm}$ of the core. The mineralogy above and below $7 \mathrm{~cm}$ is a mixture of aragonite and calcite, slightly aragonite dominated above (30 percent aragonite, 20 percent calcite), and slightly calcite-dominated below (15-20 percent aragonite, 30 percent calcite, Dean and others, 2005). Mg calcite accounts for about 13 percent of the top $2 \mathrm{~cm}$, but this occurrence is not reflected in the $\mathrm{Mg} / \mathrm{Ca}$ ratio.

Much the same pattern in leachate composition is seen in core 98-10 (fig. 7) as is seen in core $98-06$. The chemical changes and the ${ }^{210} \mathrm{~Pb}$ profile place 1912 at about 12 $\mathrm{cm}$, reflecting a higher rate of sedimentation at this site, consistent with the inferences from radiocarbon dates on the longer 1996 cores (Colman and others, 2005). As in core 98-06, $\mathrm{CaCO}_{3}$ in core 98-10 ranges between 60-70 percent, but in contrast, it is dominated by aragonite (40-50 percent) with lesser calcite (12-16 percent) in rather constant ratios throughout the core (Dean and others, 2005). Mg calcite makes up between 11-14 percent of the sediment in the top $6 \mathrm{~cm}$; but this occurrence, like that in core $98-06$, is not reflected in the $\mathrm{Mg} / \mathrm{Ca}$ ratio.

Core 98-12 from the northern basin shows the same abrupt increase in $\mathrm{Sr} / \mathrm{Ca}$ at $7.5 \mathrm{~cm}$ attributable to the 1912 event (fig. 8). However, there is no change in Fe content, and there is an actual decrease in $\mathrm{CaCO}_{3}$ across this boundary. This decrease probably reflects dilution by river-supplied terrigenous matter, the effect of which is confined to the northern part of the lake near the point of river input. Aragonite is the predominant carbonate mineral below and above $7.5 \mathrm{~cm}$ (30-40 percent, Dean and others, 2005).

Because the relative proportion of aragonite is unchanged across the 1912 boundary in all three of the short cores, the two-fold increase in the $\mathrm{Sr} / \mathrm{Ca}$ ratio seen in the post-1912 sediments must be a reflection of a significant increase in the dissolved $\mathrm{Sr} / \mathrm{Ca}$ ratio in the post-1912 lake water. The $\mathrm{Sr} / \mathrm{Ca}$ ratio in today's lake is $68 \times 10^{-4}$ (Dean and others, 2005). Considering that about half of the carbonate is aragonite, the observed increase in $\mathrm{Sr} / \mathrm{Ca}$ ratio in the sediments from $18 \times 10^{-4}$ to ca $50 \times 10^{-4}$ today suggests that diversion greatly increased the $\mathrm{Sr} / \mathrm{Ca}$ ratio in the lake because Bear River has a high $\mathrm{Sr} / \mathrm{Ca}$ ratio (ca $100 \times 10^{-4}$, Dean and others 2005). Unfortunately, $\mathrm{Sr}$ was not analyzed in the pre-1912 lake water.

\section{Sediment Traps}

Sediment traps were deployed at the same locations as the short cores (trap 1 at the site of core 98-06, trap 2 at the site of core 98-10, and trap 3 at the site of core 98-12, northern basin, Dean and others, 2005). Sediment was collected at depths of $10 \mathrm{~m}$ in all 

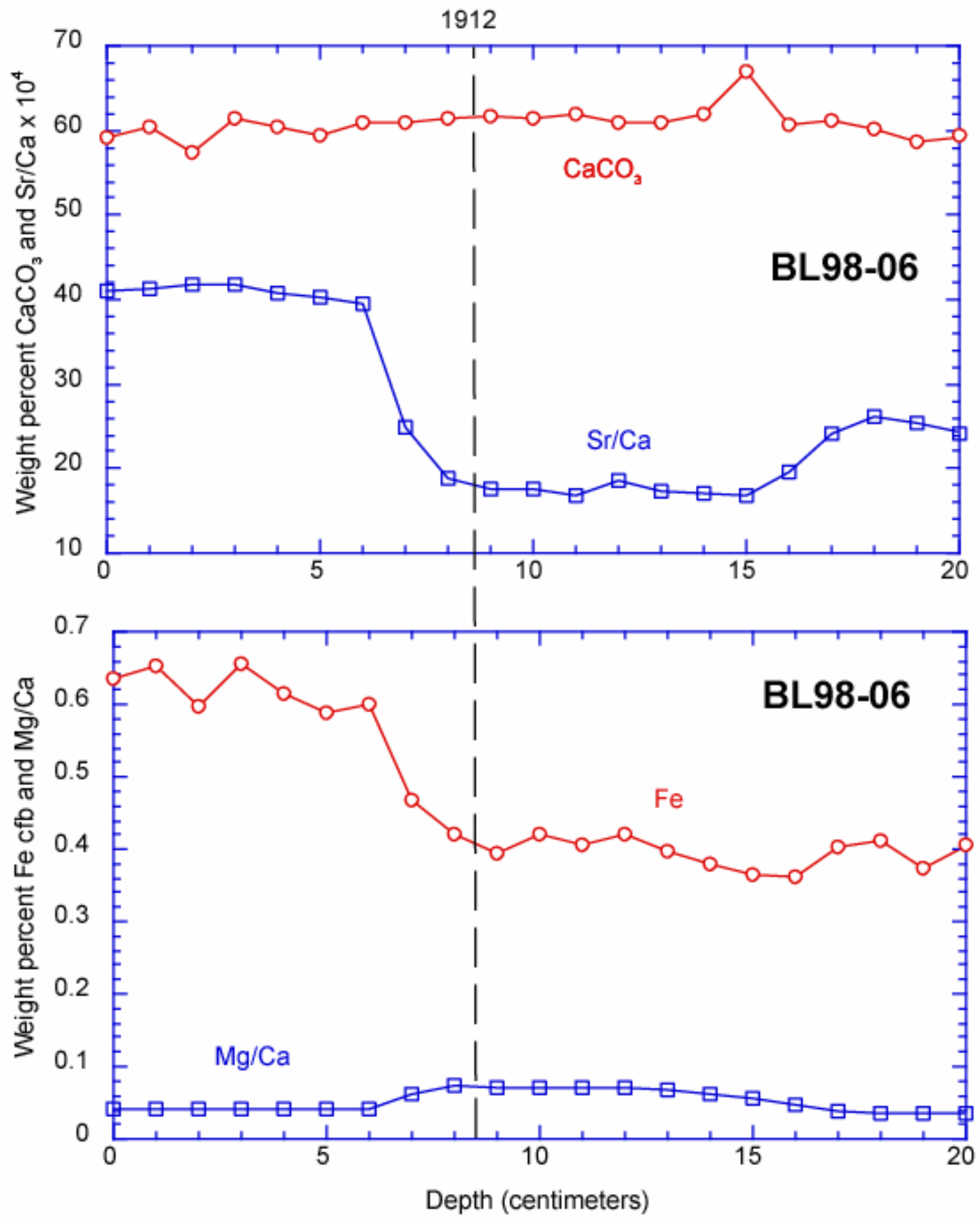

Figure 6. $\mathrm{CaCO}_{3}$ content, $\mathrm{Sr} / \mathrm{Ca}$, Fe content on a carbonate-free-basis (cfb) and $\mathrm{Mg} / \mathrm{Ca}$ for Bear Lake core 98-06 derived from chemical composition of the acid soluble component of the sediments (Appendix 5) plotted against depth. 

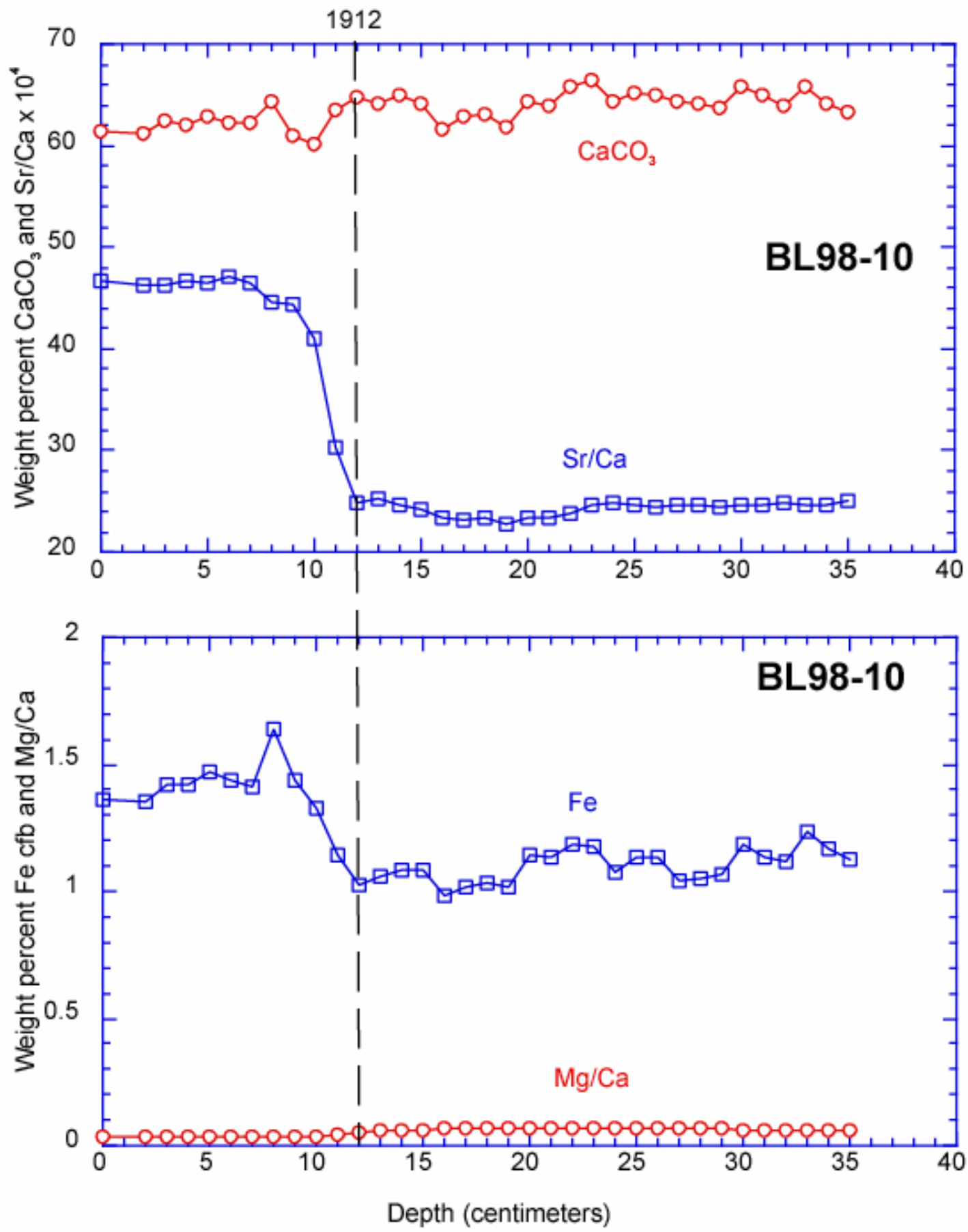

Figure 7. $\mathrm{CaCO}_{3}$ content, $\mathrm{Sr} / \mathrm{Ca}, \mathrm{Fe}$ content carbonate-free-basis (cfb), and $\mathrm{Mg} / \mathrm{Ca}$ for Bear Lake core 98-10 derived from chemical composition of the acid soluble component of the sediments (Appendix 6) plotted against depth. 

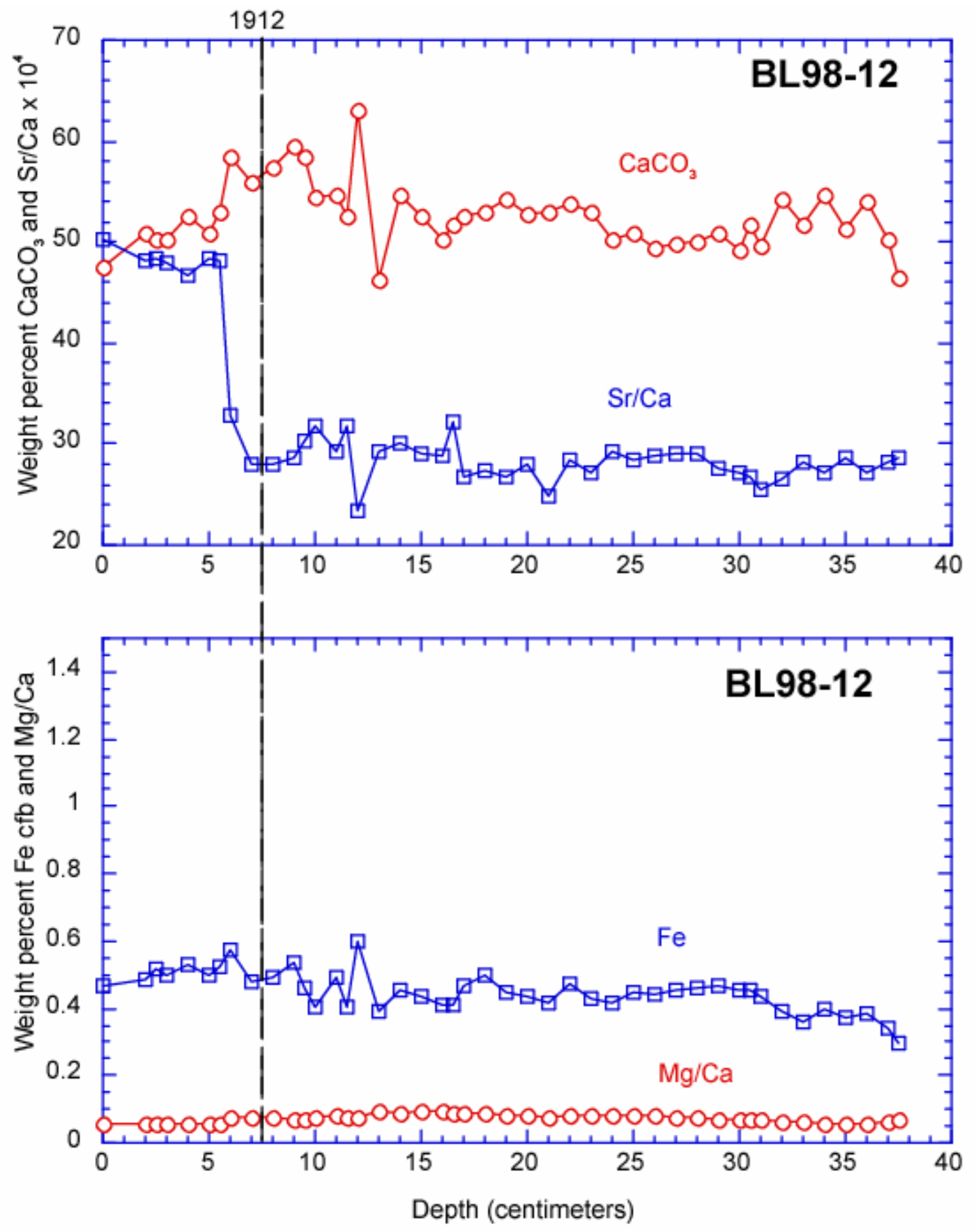

Figure 8. $\mathrm{CaCO}_{3}$ content, $\mathrm{Sr} / \mathrm{Ca}$, Fe content on a carbonate-free-basis (cfb), and $\mathrm{Mg} / \mathrm{Ca}$ for Bear Lake core $98-12$ derived from chemical composition of the acid soluble component of the sediments (Appendix 7) plotted against depth. 
three sites (shallow traps), and at $25 \mathrm{~m}$ at sites 1 and 3 and at $40 \mathrm{~m}$ at site 2 (deep traps). Results of chemical analysis of the acid-soluble fraction are presented in Appendix 8. The compositions of all of the shallow traps are similar to each other and contrast with the deep traps. The shallow traps are dominated by high-Mg calcite (Dean and others, 2005) comprising 65-78 weight percent of the samples. Mole percent $\mathrm{Mg}$ ranges from 7 to 11 percent. The deep traps are dominated by aragonite with lesser high-Mg calcite and low-Mg calcite (Dean, 2005) comprising 57-73 weight percent of the samples. The remaining component is a mixture of organic matter and terrigenous material (not analyzed). Soluble Fe ranges from 0.5 to 2.0 percent of the samples, and its linear correlation with $\mathrm{Mn}(\mathrm{r}=0.94)$ suggests that both come from iron hydroxides associated with terrigenous material. $\mathrm{Ba}$ and $\mathrm{Sr}$ are be enriched in the deep samples compared to the shallow, which is consistent with the preference of these elements for the more open crystal-lattice of aragonite.

The contrasting mineralogy in the shallow and deep traps poses the question as to the cause of precipitation. A simple experiment was conducted to precipitate $\mathrm{CaCO}_{3}$ from modern Bear Lake water. Excess reagent-grade powdered calcite was slurried with 500 milliliters of lake water, and $\mathrm{CO}_{2}$ gas was bubbled through the slurry at 1 atmosphere pressure until $\mathrm{pH}$ remained constant. The solution then was filtered to remove the powdered calcite, and the solution was allowed to equilibrate with the air, letting the excess $\mathrm{CO}_{2}$ outgas. During this process, $\mathrm{CaCO}_{3}$ became supersaturated and precipitated. The precipitate was collected and analyzed (Appendix 8) and was found to consist entirely of low-Mg calcite (1.1 mole percent $\mathrm{Mg}$ ). Calculations using lake-water chemistry and the stability of Mg-calcites (Bischoff and others, 1987) indicate that at $20^{\circ} \mathrm{C}$ aragonite and all $\mathrm{Mg}$-calcites up to 11 mole percent $\mathrm{Mg}$ are supersaturated, and that a 4 mole percent $\mathrm{Mg}$-calcite is the least soluble (that is, most stable) calcite composition (fig. 9). It is noteworthy that all calcites are more stable than aragonite. Redoing the calculation for $4^{\circ} \mathrm{C}$ (fig. 10) shows that low Mg-calcite becomes more stable over high$\mathrm{Mg}$ calcite, and that aragonite is considerably less stable than either. Surficial sediments are aragonitic and, therefore, represented by the contents of the deeper traps. That little high-Mg calcite is found in the lower traps or the sediments indicates that it must convert, presumably to low-Mg calcite in the water column before reaching $25 \mathrm{~m}$ depth. However, figure 10 shows that high-Mg calcite cannot convert to aragonite. The aragonite, therefore, must be precipitating in the deeper part of the lake by a mechanism unrelated to the precipitation of high-Mg calcite in the upper water column. Why aragonite is forming rather than the more stable low-Mg calcite must be due to kinetic processes that override thermodynamic stability, which may be the result of specific inhibition of calcite nucleation by dissolved ions such as $\mathrm{Mg}$. The source of the midwater aragonite might be the sublacustrine discharge of springs originating from karst processes in the limestone bedrock recharge area to the west of the lake.

The high-Mg calcite that precipitates in the upper water column, collected in the shallow traps, probably is biologically mediated rather than a pure inorganic precipitate. 


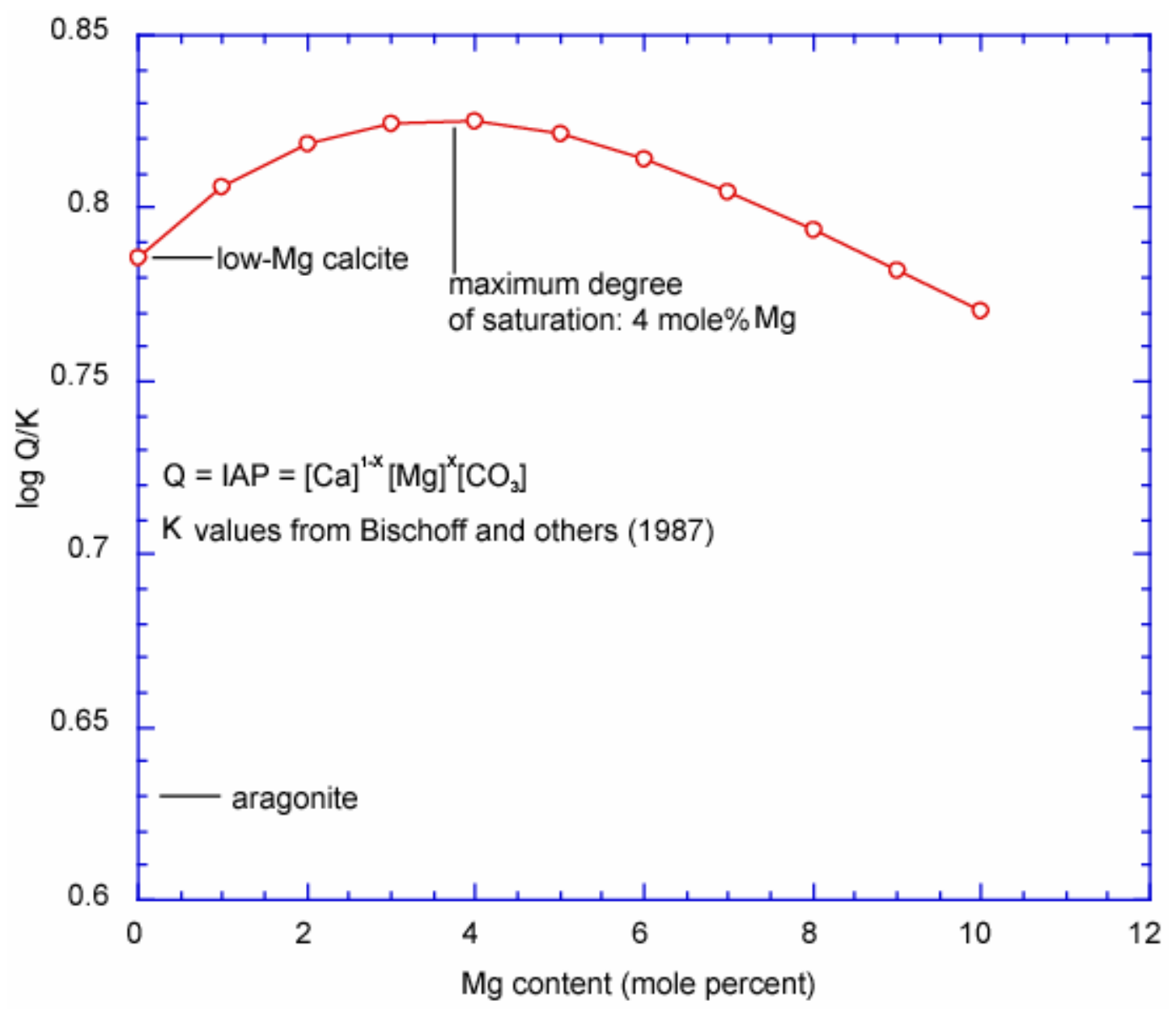

Figure 9. Saturation state of Mg-calcites and aragonite in modern Bear Lake water at $20^{\circ} \mathrm{C}$ (water chemistry from Forester, written commun.). All phases are slightly supersaturated, so any phase can theoretically precipitate. Note that aragonite is significantly less stable than any of the Mg-calcites. 


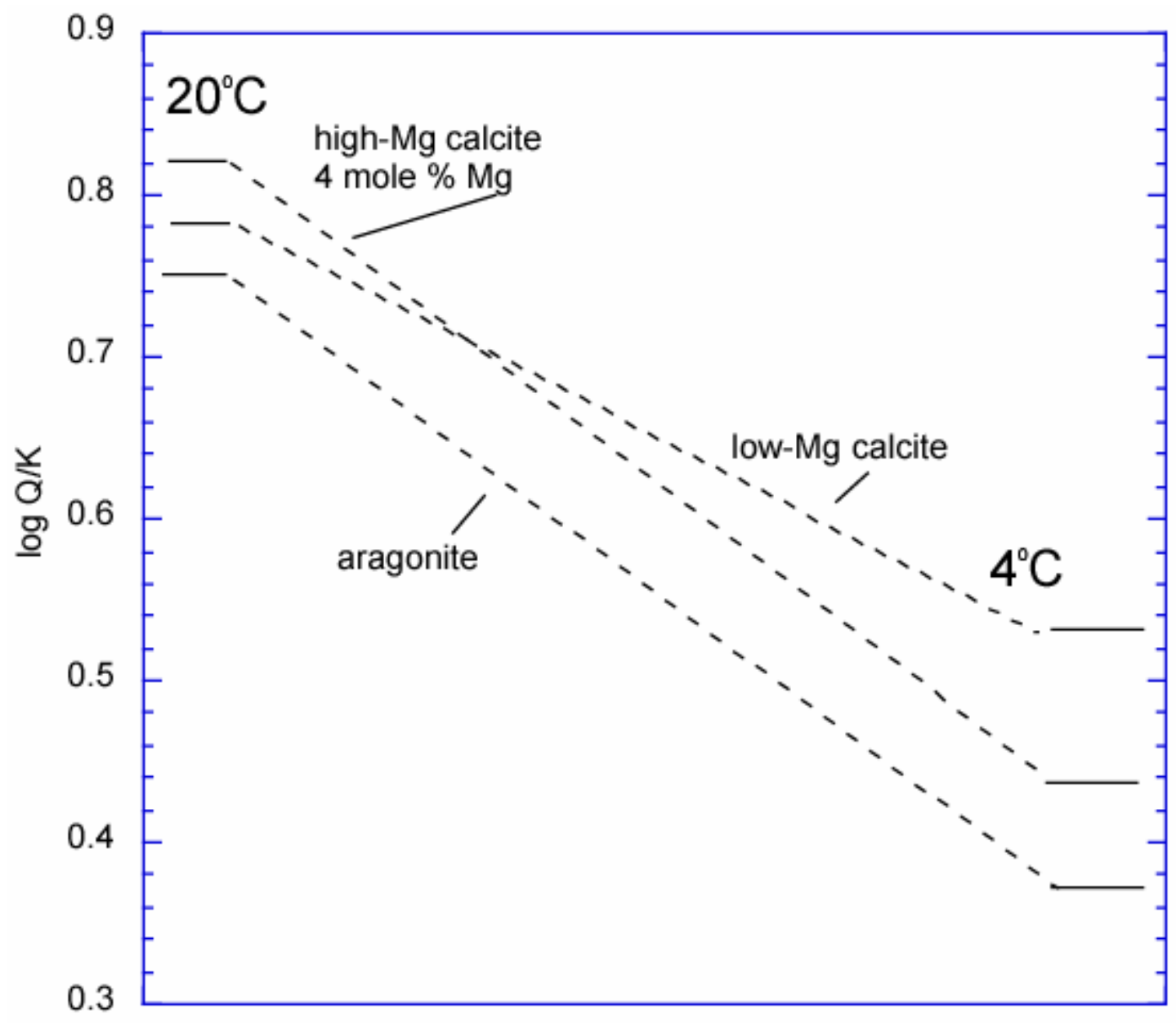

Figure 10. Change in relative saturation state of $\mathrm{Mg}$-calcites and aragonite in modern Bear Lake water as a result of cooling from $20^{\circ}$ to $4^{\circ} \mathrm{C}$. Cooling decreases the degree of saturation of all phases significantly but does not make them undersaturated. Note that low-Mg calcite becomes the most stable carbonate at $4^{\circ} \mathrm{C}$. The predominance of aragonite in the deep sediment traps and surficial sediments is due to kinetic effects rather than thermodynamic stability. 


\section{References Cited}

Bischoff, W.D., Mackenzie, F.T., and Bishop, F.C., 1987, Stabilities of synthetic magnesian calcites in aqueous solution: Comparison with biogenic materials: Geochimica et Cosmochimica Acta, v. 51, p. 1413-1423.

Colman, S., Kaufman, D., Rosenbaum, J.G., and McGeehin, J.P., 2005, Radiocarbon dating of cores collected from Bear Lake, Utah and Idaho: U.S. Geological Survey Open-File Report \#\#\#.

Dean, W., Forester, R., Colman, S., Liu, A., Skipp, G., Simmons, K., Swarzenski, P., Anderson, R., and Thornburg, D., 2005, Modern and glacial-Holocene carbonate sedimentation in Bear Lake, Utah and Idaho: U.S. Geological Survey Open-File Report 2005-1124, 23 p.

Kemmerer, B., Bovard, J.F., and Boorman, W.R., 1923, Northwestern lakes of the United States - Biological and chemical studies with reference to possibilities to production of fish: U.S. Bureau of Fisheries Bulletin 39, p. 51-140.

Rosenbaum, J.G., 2005, Magnetic Properties of Sediments in Cores BL96-1, -2, and -3 from Bear Lake, Utah and Idaho: U.S. Geological Survey Open-File Report 2005$1203,13 \mathrm{p}$.

Smoak, J.M., and Swarzenski, P., 2004, Recent increases in sediment and nutrient accumulation in Bear Lake, Utah/Idaho, USA: Hydrobiologia, v. 525, p. 175184.

Williams, J. Stewart, 1961, Recent geologic history of Bear Lake Valley, Utah-Idaho: Field Guide for $7^{\text {th }}$ annual Field Conference, Friends of the Pleistocene Rocky Mountain Section, Department of Geology, Utah State University, Logan, Utah. 